International Journal of Linguistics, Literature and Culture
Available online at https://sloap.org/journals/index.php/ijllc/
Vol. 5, No. 1, January 2019, pages: $32 \sim 42$
ISSN: 2455-8028
https://doi.org/10.21744/ijllc.v5n1.479

\title{
Preservation of Lullabies Songs in Forming Character Based on Local Wisdom
}

\author{
Nurhayati Harahap a \\ Irawaty A. Kahar ${ }^{\text {b }}$ \\ Laila Hadri Nasution ${ }^{c}$
}

Article history:

Received: 27 July 2018

Accepted: 30 November 2018

Published: 19 December 2018

Keywords:

character;

local wisdom;

lullabies songs;

oral tradition;

preservation;

\begin{abstract}
The lullabies songs is an oral tradition performed by the mother in ancient times in Indonesia. Text in the songs is loaded with local wisdom. But the negative value of globalization has had an impact on the erosion of local cultural values, and the wonder of lullabies of several ethnics in North Sumatra is almost extinct. Inventorization, and preservation of the traditional media of lullabies from oral to digital and is a way of saving and sharing the information contained in the lullabies. Aside from that it analyzes and identifies local wisdom values contained in lullabies that can be used in character formation. The method used is qualitative with content analysis approach based on the theory of hermeneutics. The results of the research are (1) the 14 lullabies while singing a child of North Sumatra ethnic's culture for the preservation of local culture, (2). The packing of digital of lullaby songs (CD/DVD) is spread through social media/website to revive the tradition of children's singing songs, (3) Identify the types of local cultural values to be utilized in the generation of children of the present generation.
\end{abstract}

2455-8028 ${ }^{\circledR}$ Copyright 2019. The Author. This is an open-access article under the CC BY-SA license (https://creativecommons.org/licenses/by-sa/4.0/) All rights reserved.

\section{Author correspondence:}

Nurhayati Harahap,

Languages and Literature Science, Faculty of Cultural Science, University of North Sumatera,

Medan, Indonesia

Email address: harahapaty@gmail.com

\footnotetext{
${ }^{a}$ Languages and Literature Science, Faculty of Cultural Science, Universitas Sumatera Utara, Medan, Indonesia

${ }^{\mathrm{b}}$ Library and Information Science, Faculty of Cultural Science, Universitas Sumatera Utara, Medan, Indonesia

${ }^{c}$ Library and Information Science, Faculty of Cultural Science, Universitas Sumatera Utara, Medan, Indonesia
} 


\section{Introduction}

The oral tradition of swinging children while singing is usually done by most ethnic mothers in Indonesia. Oral tradition is a traditional cultural activity of a community passed down from generation to generation with oral media from one generation to another, both oral (verbal) and oral (nonverbal) oral spoken words. Sibarani (2012) A mother (matrilineal) is instrumental in delivering the singing (while swinging) children based on local wisdom to shape the personality and character of the child as early as possible (Harahap, 2015). Local wisdom is historical and positive, values taken by the ancestors are then passed on orally to the next generation (Ataupah, 2004). In addition, the values of local wisdom from the songs while swinging an infant (child) is very thick with moral messages for children, so that moral messages can be used as a means to form a character (Neno Lestari \& Noor Efni Salam, 2016). The most valuable benefit of is the value of local wisdom that contains the noble values of the nation's ancestors can be used as capital to build a nation with a good and strong character (Dina Andika, 2016). It is undeniable that local wisdom is a culture that belongs to a certain society that is considered able to survive the current of globalization (Yunus, 2014). Expected to enrich the scientific knowledge based on local wisdom that includes the soft skills of conservation for future generations (Sudarmin, 2013; Rahmawati et al., 2018). But in today's reality, the negative effects of globalization have an impact on the erosion of local cultural values. The oral tradition of singing is almost extinct and is no longer known by the present generation. To fight against the extinction, one way is to re-preserve the media of the lullaby songs of the orally recorded to digital (in the form of CD/DVD), to be easily disseminated. The process of media transfer uses the theory of conservation. A theory of preservation extends the concept of digital preservation from one that is focused on sending the records (metadata) into the future to one that can also enter into the future description of the environment (Paul Watry, 2007). One expert defines the digitalization of culture as a concept of utilizing Information and Communication Technology (ICT) to improve utility in the field of culture, especially in management (Sitokdana, 2016). In addition Information and Communication Technology (ICT) is not only important for the welfare of the community but also is more important to establish a tie between different generations. In connection with that, the formation of children's characters based on local culture on the current and the coming generations can be done through singing while swinging children which have been provided by conservation.

\section{Materials and Methods}

The research used the qualitative method with content analysis approach based on hermeneutic theory (meaning comprehension). This approach can be exploited if it wishes to disclose certain value content in literary works, which include: (a) moral message, (b) educational value, (c) philological value, (d) religious value, (e) welfare value and so forth (Endraswara, 2008). Each of the elements of meaning reveals the text, the context, and the context pertaining to the oral or cultural tracer. The theory is to reveal the meaning, cultural values, and local wisdom as the foundation of formation of children. Methods of data collection through Focus Group Discussion with community/adat leaders, interviews with informants (6 people: mother/ grandmother), recording of songs, and documentation of lyrics of the lullabies songs. Informants amounted to 6 people (mother/grandmother) who is currently still doing the tradition of swinging children while singing. The unit of analysis is an oral tradition of the singing of an ethnic Mandailing child. Malay and Karo in North Sumatra Province. For the preservation of media transfer, the approach of utilizing Information Technology from oral to digital form, because digitalization is the activity of switching media information from various types of media can be done by using a variety of tape recorder (Garjito, 2002).

\section{Results and Discussions}

\subsection{Inventorization of Lullabies EthnicMandailing, Malay, and Karo}

The singing while swinging a child was performed in four villages: (1) Pagarutan Village (Tapanuli Selatan), (2) Gunung Tua Village (Mandailingness), (3) town of TanjungBalaiAsahan (Malayness), and (4) Perbesi Village Tigabinanga (Karonese). These three ethnic groups are located in North Sumatra Province of Indonesia. The perpetrators are the mother or grandmother. The tradition of singing while swinging children is a tradition that can be done at any time when parents will put the child in a swing to sleep. Swinging the child is accompanied by a song containing advice, advice, and prayer, which is a parent's habit when a child is crying and wanting to sleep (Neno

Harahap, N., Kahar, I. A., \& Nasution, L. H. (2018). Preservation of lullabies songs in forming character based on local wisdom. International Journal of Linguistics, Literature and Culture, 5(1), 32-42. https://doi.org/10.21744/ijllc.v5n1.479 
Lestari \& Noor Efni Salam, 2016). The lyrics of the song lull the child rhythmically, calmly and repeatedly. Her words are affectionate, compelled the child to to want to close his/her eyes (Noor Adeham, 2014). From the results of the inventory obtained as many as 14 pieces of children lullabies singing, 2 Malay ethnic singing, 9 Mandailing ethnic lullabies, and 3 Karo ethnic lullabies. Basically, the moral message presented in the entire singing is almost the same, but the difference lies in the rhythm of delivery, there is a melodious, seductive, so as to make the child fall asleep. The results of the content of Malay, Mandailing and Karo ethnics and the values of local wisdom contained, in the songs can be seen in Table 1, Table 2, and Table 3.

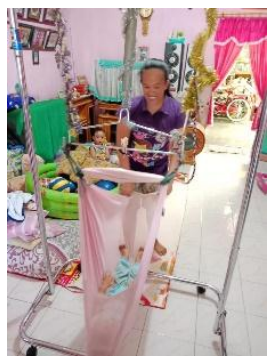

Figure1: Malay ethnics way to swing a Child

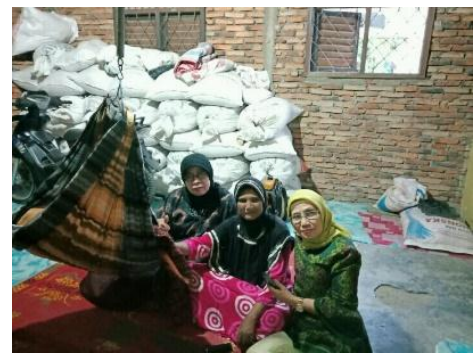

Figure 3: Mandailings ethnics way to swing a Child

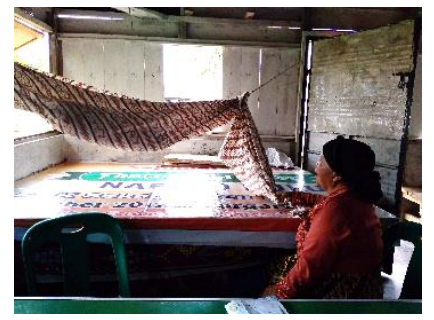

Figure 2: Mandailings ethnics way to swing a child

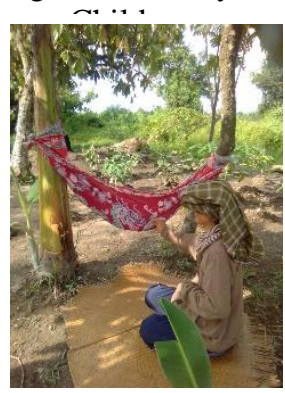

Figure 4: Karo ethnics way to swing a Child

Table 1

Inventorization of lullabies while swinging a child of the ethnic Malay and the value of local wisdom

\begin{tabular}{|c|c|c|c|}
\hline & $\begin{array}{l}\text { Texts of the lyrics of the lullabies in the } \\
\text { Malay language }\end{array}$ & English Version & $\begin{array}{l}\text { The Value of Local } \\
\text { Wisdom }\end{array}$ \\
\hline 1. & $\begin{array}{l}\text { Judul: Dodoi si Dodoi } \\
\text { Buah hatiku junjungan jiwa } \\
\text { Buah hatiku junjungan jiwa } \\
\text { Dodoi si dodoi } \\
\text { Janganlah anak suka menangis } \\
\text { Janganlah anak suka menangis } \\
\text { Ayahmu jauh ya anak dirantau orang ya } \\
\text { sayang } \\
\text { Ayahmu jauh ya sayang dirantau orang } \\
\text { ya sayang } \\
\text { Ayahmu jauh ya anak dirantau orang ya } \\
\text { sayang } \\
\text { Ayahmu jauh ya sayang dirantau orang } \\
\text { ya sayang } \\
\text { Dodoi si dodoi }\end{array}$ & $\begin{array}{l}\text { Title: Dodoi siDodoi } \\
\text { The precious child of my heart } \\
\text { sleep child sleep } \\
\text { Dodoisidodoi } \\
\text { please don't cry my dear child } \\
\text { please don't cry } \\
\text { Your father is far away in foreign } \\
\text { please dear child } \\
\text { Your father is far away in foreign } \\
\text { please dear child } \\
\text { Your father is far away in foreign } \\
\text { please dear child } \\
\text { Your father is far away in foreign } \\
\text { place my dear child } \\
\text { Dodoisidodoi }\end{array}$ & $\begin{array}{l}\text { The immersion of the love } \\
\text { of } \\
\text { the mothers for a child }\end{array}$ \\
\hline
\end{tabular}


2 Timang anakku sayang

Timang-timang anakku sayang buah hati ayahanda seorang jangan marah dan jangan merajuk sayang tenanglah, tenang dalam buaian Betapakah hati takkan riang bila kau bergurau dan tertawa mogalah jauh dari mara bahaya yang gembira sampai akhir masa

\section{[Reff:]}

Setiap waktuku berdoa pada Tuhan Yang Maha Kuasa Jika kau sudah dewasa hidupmu bahagia sentausa Timang-timang anakku sayang kasih hati permata ayahanda Tidurlah, tidur pejamkan mata sayang Esok hari bermain kembali
Title: timang-timang anakku sayang I hug you, hug you my dear dearest of fathers heart Don't be angryDon'tgrumbleStaycalmStay calm in the swingHow my heart will not be glowing when you are playful and laughing. Hopefully far from danger.And cheerful until the end of time. Every minute of day pray to the almighty God when you have grown up someday you will have a happy life. Cuddle my dearest child The love and gem of your father's heart. Sleep and close your eyes my dearest. Tomorrow we will play again
Prays of parents hoping the child be full of happiness...

Table 2

Inventorization of Lullabies while Swinging a Child of Mandailing Ethnic in Pargarutan and Gunung Tua Villages

\begin{tabular}{|c|c|c|c|}
\hline & $\begin{array}{l}\text { Text of the lyrics of the lullabies in } \\
\text { Mandailing language }\end{array}$ & Indonesian and English Version & $\begin{array}{l}\text { The Values of Local } \\
\text { Wisdom }\end{array}$ \\
\hline 1 & $\begin{array}{l}\text { Bue-bue da amang bue... } \\
\text { bue-bue da amang bue... } \\
\text { campong ale campong } \\
\text { on dope hami ro mangalap ko } \\
\text { da bujing-bujing }\end{array}$ & $\begin{array}{l}\text { Indonesian: } \\
\text { ayun-ayun anak laki-lakiku } \\
\text { ayun...ayun ayun anak laki-lakiku ayun } \\
\text { lampu teplok lampu dinding } \\
\text { baru ini kami datang menjemputmu } \\
\text { wahai anak gadis } \\
\text { English: } \\
\text { Swing swing my dear boy } \\
\text { Swing swing my dear boy } \\
\text { The kerosenelamp on the wall } \\
\text { We just come to fetch you my dear girl }\end{array}$ & $\begin{array}{l}\text { The values of love and } \\
\text { affection. }\end{array}$ \\
\hline 2 & $\begin{array}{l}\text { Magodang aek godang dainang } \\
\text { Namarmayuban ambasang dainang } \\
\text { Tibu maho magodang da inang } \\
\text { Anso marbakti tu nusa dohot } \\
\text { bangsadinang }\end{array}$ & $\begin{array}{l}\text { Indonesian: } \\
\text { Air bahsungai, anak perempuanku } \\
\text { Berhanyutan manga bacang, anak } \\
\text { perempuanku } \\
\text { Cepatlah besar, anak perempuanku } \\
\text { Supaya berbakti pada nusa dan bangsa, } \\
\text { anak perempuanku } \\
\text { The fludded river my little girl, the mango } \\
\text { bacang } \\
\text { My little girl } \\
\text { Grow up fast my little girl }\end{array}$ & $\begin{array}{l}\text { The values of serving } \\
\text { the country and nation }\end{array}$ \\
\hline
\end{tabular}

Harahap, N., Kahar, I. A., \& Nasution, L. H. (2018). Preservation of lullabies songs in forming character based on local wisdom. International Journal of Linguistics, Literature and Culture, 5(1), 32-42. https://doi.org/10.21744/ijllc.v5n1.479 
To be able to devote yourself to the country and nation my little girl

3 Bue bue dainang bue

Bue buedainang bue

Jambatan ni aek godang da borukku

Pamolusan ni Sampagul lima da orukku

Anso tarsampehon rukunna lima Pangitean nisi matua dainang Simbur maho magodang dainang Anso marbakti tu orang tua dainang

5 Bue-

bue.....modommagodangmaroa-

roa....amangmodom...

Nasouparmudasayang on alee modom

Magodang ma ambasang

Na magodang di roha-roha

Magodang ale amangpamatang

Ansouankomarsipada

6 Bue .modomamangmodom Mutikniparpidoanku ale amang Mudalangkadiamangturoha Manjalaibuluhasaparupuk Mudalangka ho amangmarsipada Manjalaiilmudohotbisuk
Indonesian:

Ayun-ayunlah anak perempuanku ayun Ayun-ayunlah anak perempuanku ayun Jembatan sebuah sungailah anak

Perlintasan Bus Sampagulnomor limalah anak perempuanku

Supaya tersampaikan rukun yang lima anak perempuanku

English:

Swing swing my little girl

Swing swing my little girl

Be a bridge my little girl

For the bus sampagul five to cross over my little girl. So that be able to complete the

five commandments of Islam my little girl

Indonesian:

Itusatukayu yang besar oh anakrempuanku

Titian orangtuaanak oh perempuanku

Cepatbesarlahoh anakperempuanku

SupayaberbaktipadaorangtuaOh anak

Perempuanku.

There is a big tree my little girl

To be a bridge for the old people, my little girl

So that you can serve your parents, my

little girl

Indonesian:

Duhai tidurlah anakku sayang

Buah hatiku tersayang tidurrlah

Besar-besar buah embacang

Tumbuh besar di rawa-rawa.

Lekaslah besar badanmu anakku

Agar lekas engkau sekolah.

English:

Oh sleep my dearest child

The love of my heart sleep, please

The embracing fruits are so big

Grown big your body my little girl

So you can go to school soon

Indonesian:

Duhai tidurlah anakku tidur

Bunga impian anakku sayang

Jika engkau pergi ke belantara

Mencari buluh dan parupuk

Pergilah nak ke sekolah.

Mencari ilmu kelak esok.
The values of religion

The values of serving the parents.

The values that child later go to school

The values hoping the child pursue learning. 
English:

Sleep oh sleep, my little girl

The flower of my dream my dear child

If you go to the wood

Finding bamboo and parupuk

Go to school oh dearest child

To pursue knowledge in the future

$7 \quad$ Campong ale campong Urat ni galinggang laut on Haru lomlom pe daboru kon Tolu kabupaten manyapai on

8 Pokenamang di Sidimpuan TorangaribayBaga-bagaa di Siboga

Mangidope au amangtuTuhan Sauttulus da baga-baga

9 Adong dope

ubegenagodangumpukmu Ulangkomabiar

Anggodidokondebata

Tola do ho ro to Tuhanmu

Anggodokonnidebata, inang

Danak ma nalobisonang
Indonesian:

Campong ale campong

Akar galingging di laut

Biar hitam pun anak perempuanku ini

tiga Kabupaten melamarnya

English:

Campong ale campong

The galingging roots at sea

Even though your skin is dark my little girl

Three regions cometoask for your hand

Indonesian:

Hari pekan di sidempuan

Besok harinya di Siboga

Aku memohon kepada Tuhan

Tercapai cita-cita yang kauimpikan

English:

The market day in Sidempuan

The next day inSibolga

I pray to the almighty god

Hopefully, you obtain all your dreams and wishes

Indonesian:

Kutahu banyak tantangan menghadangmu

Kau jangan gentar

Allah berfirman

Silakan kau memohon padaNya.

Sesuai firman Allah ananda

Agar anak lebih senang.

English:

I know there are many challenges

Do not be afraid

Allah commands

Please pray to Him

According to Allah Commandments my dear child

That you will be happy
The values of love and affection of parents toward their child.
The educational values to obtain all wishes of a child in the future.

The religion values

\footnotetext{
Harahap, N., Kahar, I. A., \& Nasution, L. H. (2018). Preservation of lullabies songs in forming character based on local wisdom. International Journal of Linguistics, Literature and Culture, 5(1), 32-42. https://doi.org/10.21744/ijllc.v5n1.479
} 
Table 3

Inventorization of Lullabies while swinging a child of the Karo ethnic and the values of local wisdom in the Perbesi Tigabinanga Village

\begin{tabular}{|c|c|c|c|}
\hline & $\begin{array}{l}\text { The text of the lyrics of the } \\
\text { lullabies in Karo language }\end{array}$ & Indonesian and English Version & $\begin{array}{l}\text { The Values of Local } \\
\text { Wisdom }\end{array}$ \\
\hline 1 & $\begin{array}{l}\text { Didongdoah anakku...... } \\
\text { Lampas mbekin ...ulangindet, } \\
\text { ulatangis....anakku } \\
\text { Didong...doah anakku... } \\
\text { ulagutululamelingesanakkuMakapa } \\
\text { gibanci man temankuarih, } \\
\text { inganumetuaanakku. }\end{array}$ & $\begin{array}{l}\text { Indonesian: Timang-timang anakku } \\
\text { Cepatlah besar, janganlah sakit, } \\
\text { janganlah menangis } \\
\text { Timang-timang anakku..sayang jangan } \\
\text { bandel agar kamu dapat menjadi temanku } \\
\text { jangan cengeng } \\
\text { Agar kamu dapat menjadi temanku di hari } \\
\text { tua. } \\
\text { English: Cuddle..cuddle my little child } \\
\text { Grow up fast, don't get sick, don't carry } \\
\text { Cuddle..cuddle my be little child don't be } \\
\text { stubborn, so you can be my friend. Don't } \\
\text { be sissy so that you can be my friend in } \\
\text { my old days. }\end{array}$ & $\begin{array}{l}\text { The values of serving } \\
\text { the parents. }\end{array}$ \\
\hline 2 & $\begin{array}{l}\text { Didong..didongdoah ..anakku... } \\
\text { Lampas gedang } \\
\text {...nandeberpandu...gelahpergitutus } \\
\text { sekolah anakku.. } \\
\text { Bengikendulah ..min ajar } \\
\text { nandeberpanduanakku..gelahpagib } \\
\text { ancijadirudang-rudang kami } \\
\text { anakku }\end{array}$ & $\begin{array}{l}\text { Indonesian: Timang-hoolan rajin sekolah } \\
\text { Agar kamu menjadi kebanggaan kami. } \\
\text { English: Cuddle..cudle my litle child } \\
\text { Grow up fast and be diligent at school } \\
\text { So you can be our pride }\end{array}$ & The value of education \\
\hline 3 & $\begin{array}{l}\text { Tunduhangg ikut unduh } \\
\text { Tunduh...lapas kammbelin } \\
\text { Bapanta Pa laws erdahin } \\
\text { Ula kali kamngadung ...oh } \\
\text { agikakana } \\
\text { Tuduh..tuduhanggiku }\end{array}$ & $\begin{array}{l}\text { Indonesian: } \\
\text { Tidur tidurlah adikku } \\
\text { Tidurlah biar cepat besar } \\
\text { Bapak kita pergi bekerja } \\
\text { Janganlah menangis adikku } \\
\text { Tidur..tidurlah adikku } \\
\text { English: } \\
\text { Sleep-sleep my little sister } \\
\text { Sleep so you can grow faster } \\
\text { Our father is going to work } \\
\text { Don't cry my little sister } \\
\text { Sleep sleep my little sister }\end{array}$ & $\begin{array}{l}\text { Love and affection for } \\
\text { Sister/brother }\end{array}$ \\
\hline
\end{tabular}

3.2 The values of local wisdom in the Singing Texts of Malay, Mandailing, and Karo ethnic children can be used in the character formation of children

To analyze the study of oral tradition and local wisdom, research method of oral tradition is used. Each oral tradition has a form and content. The form is divided into text, co-text, and context. The text has Structure, co-text has elements, and context has condition. The contents of oral tradition in the form of values or norms are crystallized from meaning, purpose, role, and function. Values and norms can be used to organize a social life called local wisdom.

The types of local wisdom are divided into two, namely the first, for peace consisting of compassion, honesty, social loyalty, and harmony and conflict resolution, commitment, positive thinking, and gratitude. The second type of local wisdom is for the welfare of hard work, discipline, education, health, mutual assistance, gender management, 
cultural preservation and creativity, and environmental care. Based on the meaning and function of the singing lullabies of the ethnic Malays, three functions of information are found in the form of messages containing local cultural values, namely (1) the value of compassion, (2) honesty and loyalty and (3) parents' prayers for a child. In Mandailing ethnic there is 5 functions of information containing the values of local wisdom (1) affection, (2) devotion to country and nation, (3) religious, (4) devotion to parents, (5) education. In ethnic Karo, there are 2 functions of information values of local wisdom that is (1) devotion to parents and (2) affection. In ethnic Karo, there are 2 functions of information values of local wisdom that is (1) devotion to parents and (2) affection.

\subsection{Reviving the tradition of lullabies while swinging a child of Malay, Mandailing and Karo Ethnic}

The oral lullabies while swinging a child in North Sumatra is no longer heard and less desirable for today's generation. This condition may be due to the less attractive way of delivery. To overcome those facts, efforts should be done so that the tradition of lullabies while swinging a child in the original media in the past, be revived with different appearances and versions. One way is through the re-preservation of the lullabies while swinging a child in the original media i.e informant. Then record the songs in the recorder, change the arrangement of the music that accompanies the singer and finally the creation of the video clip (in the form of (CD/DVD), as to be accepted by now generation. And then ready to be disseminated through social media such as youtube, Instagram etc. In order, the lullabies while swinging a child can be accessed more broadly a North Sumatera ethnic's website should be created. The ways in reviving the traditional lullabies while swinging a child of Malay, Mandailing and Karo ethnic's children can be seen in Table 4.

Table 4

Reviving the tradition of Lullabies While Swinging a child of Malay, Mandailing and Karo ethnics

\begin{tabular}{|c|c|c|c|}
\hline \multicolumn{2}{|c|}{ Activities } & Instruments & Output \\
\hline 1 & $\begin{array}{l}\text { To record children's lullabies of Malay, } \\
\text { Mandailing, and Karo ethnics. }\end{array}$ & Recorder & $\begin{array}{l}\text { Recording of children's } \\
\text { lullabies and informants } \\
\text { of each ethnic. }\end{array}$ \\
\hline 2 & $\begin{array}{l}\text { Re-arrangement of the music of } \\
\text { lullabies songs while swinging a child. }\end{array}$ & Music & $\begin{array}{l}\text { Lullabies songs in the } \\
\text { new style }\end{array}$ \\
\hline 3 & Choosing the Singer. & The singer & $\begin{array}{l}\text { Reviving songs while } \\
\text { swinging a Child by } \\
\text { professional Singer. }\end{array}$ \\
\hline 4 & Video shooting of the singer. & Camera video & $\begin{array}{l}\text { CD/DVD of lullabies } \\
\text { songs while swinging a } \\
\text { child of ethnics Malay, } \\
\text { Mandailing, and Karo in } \\
\text { the places in North } \\
\text { Sumatera Province } \\
\text { Indonesia. }\end{array}$ \\
\hline 5 & $\begin{array}{l}\text { Dissemination of the lullabies songs } \\
\text { while singing a child of Malay, } \\
\text { Mandailing, and Karo ethics. }\end{array}$ & $\begin{array}{l}\text { Social Media, i.e. } \\
\text { youtube, and website. }\end{array}$ & $\begin{array}{l}\text { Reviving the lullabies } \\
\text { songs while swinging a } \\
\text { child of ethnics in North } \\
\text { Sumatera Ut }\end{array}$ \\
\hline
\end{tabular}

\section{Conclusion}

The results of the analysis from the research data show that there are 14 songs of Malay, Mandailing and Karo ethnics lullabies in North Sumatra Province. North of Indonesia, that can be used to assist the government in preserving the tradition of lullabies that almost extinct. There are 12 functions of the information of local wisdom values contained in the text of children's lullabies, there are (1) love and affection, (2) devotion to both parents, the nation and country, (3) education for the children to study the future, (4) religion, (5) honesty, (6) prayers and expectations of parents. The values of local wisdom can be utilized for the character formation of children based on local wisdom. Aside from that,

Harahap, N., Kahar, I. A., \& Nasution, L. H. (2018). Preservation of lullabies songs in forming character based on local wisdom. International Journal of Linguistics, Literature and Culture, 5(1), 32-42. https://doi.org/10.21744/ijllc.v5n1.479 
preservation of media of children lullabies from oral to digital in the form of CD/DVD products should be done. It is expected that they can be widely disseminated and accessible via social media and website in the aim of reviving the several ethnic lullabies songs in North Sumatra.

Conflict of interest statement and funding sources

The author declared that no competing interest. The study was financed by TALENTA as a research program in USU.

Statement of authorship

The authors have a responsibility for the conception and design of the study. The authors have approved the final article.

Acknowledgments

This research was financially supported by Universitas Sumatera Utara in according to TALENTA Universitas Sumatera Utara Research Contract for the Year 2018 Number 2590/ UN5.1.R/PPM/2017 dated March $16^{\text {th }}, 2018$. 
References

Adeliani, N. (2015). Lagu Menidurkan Anak pada Masyarakat Banjar: Kajian Bentuk, Makna, dan Fungsi. Al-Banjari: Jurnal Ilmiah Ilmu-Ilmu Keislaman, 13(2).

Ataupah. (2004). Peluang Pemberdayaan Kearifan Lokal Dalam PembangunanKehutanan. Kupang: Ayatrohaedi, (Ed). 1986. Kepribadian Budaya Bangsa (Lokal Genius). Jakarta: Pustaka Jaya

Endraswara, S. (2008). Metode penelitian sastra: Epistemologi, model, teori, dan aplikasi. Yogyakarta: Medpress.

Garjito (2002). Pengantar Pelestarian Bahan Pustaka dan Arsip. Jakarta: Perpustakaan Nasional RI

Harahap, R. (2015). Tradisi Membuai Anak Bayi Pada Masyarakat Angkola Mandailing (AM). Proceeding Tradisi Lisan Dalam Sistem Matrilinial 2015 Fakultas Ilmu Budaya Universitas Andalas.

Lestari, N., \& Salam, N. E. (2016). Etnografi Komunikasi Tradisi Ayun Budak Pada Adat Melayu Siak di Kota Dumai Provinsi Riau. Jurnal Online Mahasiswa (JOM) Bidang Ilmu Sosial dan Ilmu Politik, 3(2), 1-15.

Marhayani, D. A. (2016). Development of Character Education Based on Local Wisdom in Indegenous People Tengahan Sedangagung. JETL (Journal Of Education, Teaching and Learning), 1(2), 66-70. http://dx.doi.org/10.26737/jetl.v1i2.40

Nasution, M. K., Nuradi, T. E., \& Syah, R. (2017). SumutSiana: A framework for applying ICT to preserve the cultural heritage of Sumatera Utara Indonesia. Journal of Telecommunication, Electronic and Computer Engineering (JTEC), 9(2-4), 123-128.

Rahmawati, N. N., Kumbara, A., \& Suda, I. K. (2018). Multiculturalism towards religious life in tewang tampang village: moral education implementation based local wisdom. International Journal of Linguistics, Literature and Culture, 4(6), 63-71. https://doi.org/10.21744/ijllc.v4n6.408

Sibarani, R. (2012). Kearifan Lokal: Hakikat, Peran, dan Metode Tradisi Lisan. Asosiasi Tradisi Lisan (ATL).

Sibarani, R. (2015). Pembentukan Karakter Langkah-langkah Berbasis Kearifan Lokal. Jakarta: Asosiasi Tradisi Lisan.

Sitokdana, M. N. (2015). Digitalisasi Kebudayaan di Indonesia. In Seminar Nasional Teknologi Informasi dan Komunikasi (SENTIKA), Yogyakarta, Indonesia.

Sudarmin, E. S. R. P., Pujiastuti, R. S. E., \& SKM, M. (2013). Scientific Knowledge Based Culture and Local Wisdom in Karimunjawa for Groeing Soft Skills Conservation. International Journal of Science and Research (IJSR), 7582.

Watry, P. (2008). Digital preservation theory and application: Transcontinental persistent archives testbed activity. International Journal of Digital Curation, 2(2). https://doi.org/10.2218/ijdc.v2i2.28

Yunus, N., Rasyid, M. N., \& Bintang, S. (2014). Perlindungan hukum atas hak cipta program komputer) Kajian Normatif dan Sosiologis di Kota Banda Aceh). Jurnal Ilmu Hukum, 2(2).

Harahap, N., Kahar, I. A., \& Nasution, L. H. (2018). Preservation of lullabies songs in forming character based on local wisdom. International Journal of Linguistics, Literature and Culture, 5(1), 32-42. https://doi.org/10.21744/ijllc.v5n1.479 


\section{Biography of Authors}

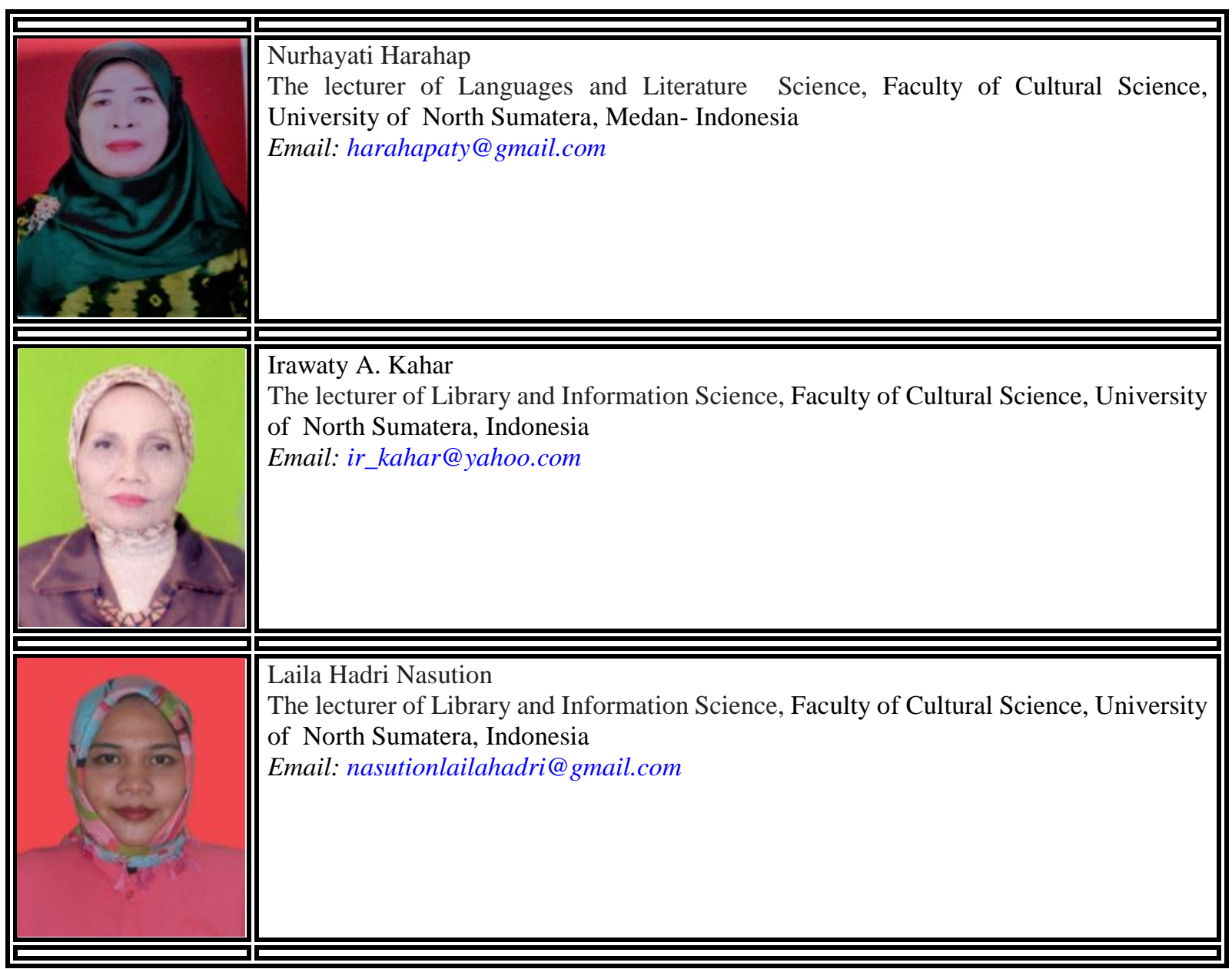

